\title{
A Parallel Evolution? Issues in Vernacular Architecture and the Development of Church Building in Syria and Georgia
}

\author{
A Brief Overview of the Origins of Christian Architecture in Syria \\ and Georgia
}

Having briefly introduced the regions under discussion in this work and begun to explore some of the linguistic and geographical confusion surrounding the relationship of Kartli and its neighbouring territories in late antiquity, we must now turn to the extant material culture and see if archaeology and art history can cast any light on whether there were trading links or other modes of contact clearly demonstrable between Syria and Mesopotamia and the Caucasus during this period. One logical place to start would seem to be to examine the evolution of Christian architecture in these different regions, given that a Syrian influence is often claimed for a variety of early churches in Georgia. However, before we move on to the specifics it is necessary to provide a brief overview of what we know about the evolution of ecclesiastical architecture both immediately before, and in the generations immediately after, the Peace of Constantine in the first half of the fourth century CE.

Whilst it is widely accepted that the first securely dated Christian place of worship anywhere in the world is the house-church at Dura Europos beside the River Euphrates in Syria, it is not until the second half of the fourth century that we find the 'Church' as a specific building constructed for Christian meetings and rituals becoming relatively commonplace. After the edict of Milan was promulgated in 313 there was no reason why Christians could not worship openly, but naturally it took time for early adherents of the faith to adapt to their new circumstances. It is therefore in the second half of the fourth century that we begin to find clear archaeological evidence for Christian places of worship in early centres of the faith such as Syria, Asia Minor, Rome and North Africa.

Although the traditional conversion narrative places the evangelisation of Iberia/Kartli in the 33 os there has long been a belief in Georgian academia that the first churches were extremely small and therefore it was not until the later fifth century or early sixth century that substantial stone-built churches

(C) EMMA LOOSLEY LEEMING, 2018 | DOI:10.1163/9789004375314_004

This is an open access chapter distributed under the terms of the prevailing CC-BY-NC License at the time of publication. 
evolved. ${ }^{1}$ A lot of this is an argument from silence because, aside from the tiny cruciform chapel at Samtavro believed to have been built beside the bush where St. Nino took up residence and the odd 'basilica' at Nekresi, ${ }^{2}$ until recently no churches in Georgia had been ascribed to the fourth century. In the west of the country there have been archaeological reports asserting that there are churches in Bichvinta/Pitsunda, the ancient Pityus, that are even earlier than the fourth century ${ }^{3}$ but extremely early dates must be treated with caution due to the swirling claims and counter-claims made over the history and sovereignty of Abkhazia. ${ }^{4}$ This is complicated by the fact that a number of these assertions concerning early churches are made by Russian scholars, whose conclusions are then rejected by Georgians as a matter of principle.

The argument that early churches were tiny structures that could hold only as few as two or three people at one time has been strengthened by the fact that most research carried out into the material culture of this period has been undertaken by architectural historians and there is a great unwillingness to challenge the typology of early church architecture established in the first half of the twentieth century by the acknowledged founder of Georgian art history, Giorgi Chubinashvili. With the death of Chubinashvili in 1973 and then the end of the Soviet Union in December 1991 there began a period of stagnation in Georgian art historical scholarship, exacerbated by the civil war in the early 199os, meaning that studies of ecclesiastical architecture have in general progressed little since Chubinashvili's time. There is an unwillingness to chal-

1 Chubinashvili returned to this question a number of times over his career and so his ideas on the evolution of (small) early churches can be found in Kartuli khelovnebis istoria, vol. 1, Sakhelgami; Tbilisi, 1936, Arkhitektura Kakhetii. Issledovanie razvitiia arkhitekturyvvostochnor provintsii Gruzii v IV-XVIII vv., Academy of Sciences of Georgia; USSR, 1959 and (in an English translation of a 1970 article in Russian) in 'On the initial forms of Christian Churches' in Mgaloblishvili, Tamila (ed.), Ancient Christianity in the Caucasus, Curzon; Richmond, 1998, pp. $185^{-195}$.

2 For more on Nekresi see below.

3 Khrushkova, L.G., 'The Spread of Christianity in the Eastern Black Sea Littoral (Written and Archaeological Sources)', Ancient West and East 6 (2007), pp. 177-219.

4 For example see Gamakharia, Jemal, Beradze, Tamaz \& Gvantseladze, Teimuraz (eds.), Assays (sic.) from the History of Georgia. Abkhazia from ancient times till the present days, Ministry of Education and Culture of Abkhazia, Institute and Ethnology of Iv. Javakhishvili; Tbilisi, 2011. This is an officially published document that has been prominently displayed in a display cabinet in the entrance to the National Parliamentary Library of Georgia and which follows the officially sanctioned state interpretation of the history of Abkhazia. The partial and flawed nature of the essays in the book attest to the fact that Soviet tactics of controlling historical narratives are still acceptable in post-communist Georgian society. 
lenge a long-established status quo that places the known monuments in a firm chronological and typological framework.

Separately from the discipline of art history there have been a series of archaeological excavations concentating on Classical period sites in Kartli. As with many other countries in the Near East and Caucasus there has long been an archaeological bias towards the earliest periods of human evolution through to the perceived grandeur of the Graeco-Roman era, but late antiquity which is referred to as being 'early medieval' in contemporary Georgia, has thus far received little attention from archaeologists. This means that assumptions are being made about the society and material culture of this era based upon written sources that were generally written down several centuries after the events they purport to recount and art historical analysis of the extant standing architecture of the period - which is dominated by ecclesiastical sites and the substantial body of carved stone stelae and reliefs that have come down to the present day.

Obviously, without archaeological excavation we are limited in what conclusions we can draw as to the earliest evolution of church ritual and Christian practice in Kartli. If we are primarily preoccupied with how far the interior disposition of these early churches may have changed since their construction it is perhaps easy to accept the official interpretation that monumental church construction only commenced in fifth to sixth century Kartli and that earlier ritual practice was confined to extremely small and simple chapels. ${ }^{5}$ However if we accept the premise that Christianity took root as early as the first half of the fourth century in Kartli, and archaeological evidence appears to support this assertion, then where did people worship when they came together to participate in rituals as large congregations? At what period does the 'church' in the sense of a clearly designated Christian ritual space become established as a recognisable place of Christian worship? Does this process happen later in Kartli, or do church buildings develop independently at the same time as they are beginning to appear in other christianised territories such as Syria or Asia Minor?

5 Thanks are due to Professor Nodar Bakhtadze of the Simon Janashia State Museum of Georgia and Ilia State University for posing the question that led to this line of thought. He argued that by accepting the assertions of Chubinashvili in an unquestioning manner, various Georgian scholars have ignored or skewed their interpretation of data to fit the accepted chronology rather than allowing the data to be interpreted in the most logical, and probable, manner. 


\section{The Availability of Construction Materials and the Evolution of the 'Church' as a Building Type}

Surprisingly for a country that is so fiercely proud of its national traditions and often presents a strongly partisan view of its past, there has been little consideration of the possibility that a native ecclesiastical tradition was entrenched as early as the fourth century. Yet when this possibility is considered there is no logical reason why this should not have been the case. Georgia is wealthy in terms of natural resources and high-quality stone is easily available in the centre and south of the country, with Bolnisi tuff being especially prized for its aesthetic qualities. In the High Caucasus schist and slate are used to construct the traditional towers of the mountain peoples. However towards the east of Georgia in the region of Kakheti there is a lack of high-grade building materials. Here all but the most prestigious buildings are constructed of stones largely salvaged from the pebbles and boulders of various dimensions that are carried along as part of the seasonal mudflow that dominates the main watercourses. ${ }^{6}$ This lends itself to a more rustic style with irregular stone courses that may vary in hue and lack the grandeur of the well-dressed masonry found in southern and central Kartli.

With the exception of the high plateau bordering Armenia to the south west and the arid steppe bordering Azerbaijan to the south east, Georgia has a plentiful supply of forests that are capable of providing timber for construction purposes, and historically most Georgian regions outside the high mountain cultures have favoured a traditional architecture that combines a wooden superstructure on a stone foundation. This can vary from the stone buildings with elaborate wooden balconies native to Tbilisi through to the Mingrelian Oda house where a single storey wooden house is balanced on stone supports to allow ventilation in summer and protect against marshy ground in winter, but it is clear that stone and wood have always been plentiful in Georgia, thus allowing for experimentation in architecture and allowing for the growth of a diverse range of vernacular traditions.

These options were not available to the early Christians of Syria. With the exception of Lebanon, all the territories of Greater Syria ${ }^{7}$ lacked forests and the

6 See Tsereteli, Emil, Gongadze, Merab, Bolashvili, Nana, Lominadze, Giorgi, Gaprindashvili, George \& Gaprindashvili, Merab, 'Mudflow Phenomena in Eastern Georgia (Kakheti Region) and Their Development Trends Related to Climate Change', International Journal of Scientific Research 3:2 (2014), pp. 193-197 for images of the varying sizes of stone carried by these flows coming down from the high Caucasus.

7 Syria, Lebanon, Jordan, Palestine, Israel and the Hatay region of Turkey in today's terms. 
kind of timber necessary for large building programmes. Wood was a precious resource and particularly necessary for the upper floors of buildings or for providing the framework to support tiled roofs. In the western regions there were plentiful sources of good quality stone but to the east options were more limited. Along the course of the Euphrates there was a supply of gypsum, but this was friable and liable to dissolve on prolonged contact with water. Elsewhere in the steppe and desert options were even more limited and mud brick architecture was employed for the overwhelming majority of buildings, with only the most well endowed projects being able to afford the cost of transporting stone to more remote eastern territories.

\section{The Problem of Dating and Changing Interpretations of Late Antique Society}

When it comes to considering the date of the first churches in both regions it is widely acknowledged how complex the issue can be. The house-church at Dura Europos is securely dated to the mid-third century as it was active in the years immediately before the town was destroyed by the Sassanians in $256 \mathrm{CE}$. Naturally there are few situations where we can be so precise about when a building ceased to be active-it is for this reason, rather than for any major cultural similarities, that Dura Europos is often linked with Pompeii in popular imagination. ${ }^{8}$ Elsewhere we have to rely on the often scant epigraphical data or solely on typological studies of architectural types. The shortcomings of the typological method are being increasingly highlighted by modern technological advances in archaeology, which, perhaps unsurprisingly, show earlier methods to have significant shortcomings as they often had to rely on only a partial view of the evidence. In western Syria this has been illustrated by rapidly changing interpretations of how society changed during the early Islamic era.

Whilst the old assumption that the disruption of Levantine society in the seventh century was largely a result of the expansion of Arab tribes out of the Arabian Peninsula has long been discredited, it was not until the end of the twentieth century that archaeology began to suggest plausible alternative narratives to explain why the majority of meaningful building campaigns on the Syrian Limestone Massif appeared to come to an end after the first decade of the seventh century. ${ }^{9}$ The old paradigm was examined by Kennedy in his

8 See for example https://www.le.ac.uk/ar/stj/dura.htm where the epithet is used on the University of Leicester website discussing their excavations at the site.

9 See the magisterial three volume work by Georges Tchalenko Villages antiques de la Syrie du 
influential 1985 article 'From Polis to Madina: Urban Change in Late Antique and Early Islamic Syria'.10 Here he convincingly argued against a binary narrative that posited a sudden break or dislocation in late antique Syria but instead demonstrated a gradual decline and societal change that saw RomanoByzantine culture slowly evolve and adapt into an early Islamic society; in urban terms this was the change from the Roman Polis to an Islamic Madina referenced in the title of his article. This position was further expanded in the following decade with Foss' 'Syria in Transition, A.D. $55^{\circ}-75^{\circ}$ '11 and research into how centres of population not only contracted but also, in some cases, expanded and moved location into marginal zones on the edge of the fertile crescent, continued into the current century with research conducted by Geyer. $^{12}$

Together these studies have convincingly demonstrated that survey methods alone have given us only a partial story as to how Syrian society functioned in late antiquity and that it was only when survey was used in conjunction with other archaeological data that a more nuanced and accurate picture of late antique and early Islamic Syria was able to emerge. However, to add a note of caution to the proceedings, it must be noted that despite the exceptional volume of late antique architecture still extant in Syria relatively few excavations concentrating on late antiquity had been undertaken in Syria before the outbreak of the civil war in 2011. This picture was changing and more archaeologists, in particular in Syria itself, were choosing to specialise in this period around the time the war began but the progress made in the early part of the twenty-first century has been placed in limbo by the hostilities.

That the survey work occurred at all was due to the fact that Georges Tchalenko, a fully-trained architect, was engaged by the French Mandatory Authorities in Syria to restore Qal'at Sem'an in the 193os and for a variety of personal

Nord. Le Massif du Bélus à l'époque romaine. Bibliothèque archéologique et historique 5o, Paul Geuthner; Paris, 1953. This work has never been surpassed, but as Tchalenko himself would have been the first to acknowledge, the work is based on survey rather than extensive excavation and forming conclusions from extant remains alone can significantly skew our understanding of the historical picture.

10 Kennedy, Hugh, 'From Polis to Madina: Urban Change in Late Antique and Early Islamic Syria', Past and Present 106 (1985), pp. 3-27.

11 Foss, Clive, 'Syria in Transition, A.D. 550-75o: An Archaeolological Approach', Dumbarton Oaks Papers 51 (1997), pp. 189-269.

12 Geyer, Bernard, 'Expansion and Decline of Syria's Arid Margin', The Arab World Geographer 5/2 (2002), pp. $73^{-84}$. 
reasons stayed on to devote his working life to the region. ${ }^{13}$ This brings us to another methodological anomaly when comparing data from Syria with that of comparable information from Georgia. In Syria art history and architectural history do not appear as academic disciplines in institutes of tertiary education, or indeed as subjects at any educational level. Therefore these questions are looked at in terms of archaeological data, whilst historians consider the texts and epigraphic evidence and architects are called in solely to consider issues relating to conservation and consolidation of ancient structures; art history and its related skills are not usually tools in the study of the Syrian past. On the other hand art history and architectural history are two highly regarded disciplines in Georgian society and this recognition formally began with practitioners such as Giorgi Chubinashvili being accorded the full rank of Academician in the Georgian Academy of Sciences-a highly sought after privilege in Soviet society.

\section{Disciplinary Boundaries within the Humanities and Methodological Problems}

In Georgia the lacunae we encounter in late antique studies appear to relate more to issues of ancient chronology and matters of religious belief than they do to a gap in the academic landscape of the country. Above all it could be argued that the issue is a methodological crisis provoked by a rigid philosophical stance on the role and significance of various academic disciplines. As in Syria, Georgia is a poor country with an overabundance of exceptional archaeological resources. Both have sites reaching back to the earliest periods of human activity, with Dmanisi in Kvemo Kartli (Southern Georgia) providing archaeological evidence for the first human remains yet found outside of Africa. With this embarassment of riches, scarce resources are targeted towards these early sites of international significance. Later periods receive less attention unless they possess another outstanding feature-in most cases this means sites that are aesthetically pleasing and have to potential to generate a significant income from tourism with Palmyra in Syria and Uplistsikhe in Georgia both notable sites to fall into this latter category. Therefore in practical terms archaeological research tends to end with the waning of the Roman Empire and later periods are neglected by comparison.

\footnotetext{
13 See Tchalenko, John in Tchalenko, Georges, with additional material by Tchalenko, John \& Loosley, Emma, Notes on the Sanctuary of St. Symeon Stylites at Qal'at Sim‘ān, Brill, forthcoming.
} 
There is also a religious element to this chronology in both countries; with the official recognition afforded to Christianity in the early fourth century, late antique archaeology is often viewed solely through the prism of religionnamely how the spread of Christianity impacted on the wider culture of the Roman Empire as it fell to 'barbarian' peoples in the west and morphed into what was later called the Byzantine Empire in the east. How this spread of Christianity is interpreted is, naturally, impacted by the circumstances of contemporary societies and in this case the divergence of attitude is made even more extreme by the present circumstances of these two countries.

Syria was one of the first countries to embrace Islam, so much so that the first Islamic dynasty - the Umayyads - chose Damascus as their capital. Therefore from the seventh or eighth century Syria can be described as a Muslim country. However, whilst the wars of the late twentieth and early twenty-first centuries have accelerated the exodus of Christians from the Middle East, a significant Christian minority remained, and indeed thrived, even after Islam became the dominant faith of the region. The impact of this on archaeological practice manifests itself as a privileging of Islamic, particularly early Islamic, archaeology with a concentration on sites linked to the Umayyads and then an emphasis on sites linked with particularly significant moments of Arab history; this has meant that monuments linked to personages such as Nur al-Din who unified much of the Bilad al-Sham and Salah al-Din who triumphed against the invading western Crusaders have received a great deal of attention. As an extension of this, and again working on the rationale that certain sites have potential to generate income from tourism, Crusader sites have also often been explored. Obviously from a methodological point of view this emphasis on Islamic identity is problematic as it essentially means that there are two schools of archaeological practice in Syria; those who work on the earlier periods and look at society in its entirety and those who work on the Islamic era, and as is implied by that term, interpret the data first and foremost through an Islamic perspective. However, despite the obvious shortcomings of this practice it does mean that more modern periods, even up to the twentieth century in some rare cases such as at the Citadel of Damascus, ${ }^{14}$ have been explored by archaeologists in Syria.

14 In the Citadel of Damascus a Franco-Syrian team recorded data from the 1920s when the French Mandatory Authorities adapted the site for use as a prison-a situation that remained the same until the gaol was finally closed in 1986, see Berthier, Sophie, 'La Citadelle de Damas: les apports d'une étude archéologique', in Kennedy, Hugh, Muslim Military Architecture in Greater Syria: From the Coming of Islam to the Ottoman Period, Brill; Leiden, 2006, pp. 151-164. 
In Georgia religion or specifically Christianity, both its absence and its presence, have had a disproportionate impact on the study of material culture. Under Soviet rule the archaeology of Christianity was not a permissible area of study and this is a strong contributory factor in why there is, with only one or two exceptions, no current tradition of post-Classical archaeology in the country. Instead the academic literature clearly delineates a break whereby the discipline of archaeology dominates until the first centuries of the Common Era and then, in the fifth century, the story is picked up by art historians. Confusingly for outsiders the fifth century onwards is designated as the 'medieval period' by Georgian scholars, ${ }^{15}$ whilst this is technically correct with the (somewhat arbitrary) date for the beginning of the Middle Ages accepted as being 476 and the abdication of Romulus Augustus, the last Roman Emperor in the west, most specialists working on late antiquity would categorise the fifth century as being firmly in that period. Whatever your perspective, a span of a thousand years seems excessive for any one historical period and for this reason alone it would seem to make sense to encourage a more sophisticated division of period than merely early, middle and late medieval. Given that Christianity is widely accepted as arriving in Georgia in the first half of the fourth century, this creates an extra difficulty as we have around a hundred years unaccounted for before the Georgian medieval era is deemed to begin, something that happens almost in parallel with the institution of the Georgian alphabet.

In fact it is the pivotal role of the creation of the Georgian alphabet that appears to have created the dislocation between how the fourth and fifth centuries are studied in Georgia; in the fourth century Georgian inscriptions and record-keeping of all forms relied on non-native scripts to record information ${ }^{16}$ and it was not until the fifth century that the creation of a new script specifically to record the Georgian language encouraged the evolution of an indigenous literary culture. Therefore Kartvelology ${ }^{17}$ entered a new era at this time and, perhaps as a philosophical or psychological reaction to this defining moment, in the twentieth century a pattern emerged whereby archaeologists concentrated on the periods up until the fourth century CE but thereafter the past was explored primarily through the disciplines of history and art history with

\footnotetext{
15 See http://museum.ge/index.php?lang_id=ENG\&sec_id=69\&info_id=13955 (Accessed 26.01.2017) to see a summary of the "Medieval Treasury" exhibition opened at the Simon Janashia National Museum of Georgia in June 2016. The text summarises the highlights of the display and includes artefacts dating back to the fifth or sixth centuries in this description demonstrating that this era is viewed as 'Medieval' in Georgia.

16 See chapter 1.

17 The study of Kartvelian history, languages, religions and culture.
} 
written texts taking centre stage and monuments being used to support the hypotheses formulated on reading the oldest Georgian literary works.

It is only recently that the archaeology of early Christian sites and other locations linked to events relating such as the Arab and Persian invasions of the country have come to be regarded as profitable areas of study. First of all, as mentioned above, post-Classical monuments have been primarily the objects of art historical research and the clear boundaries as to which periods needed archaeological study and which were 'historical' periods needing to be studied by the different branches of historical research largely prevented archaeological methodologies being applied to post fifth-century CE sites. Monuments or archaeological sites have particularly received attention if there has been a perceived link with a formative figure of the Georgian past—for what Western Europeans would designate the 'High Middle Ages' there has been particular focus on the reigns of King Davit Aghmashenebeli (King David the Builder) from 1089 until 1125 and Queen Tamar (known in Georgian as King Tamar) whose rule from 1184 to 1213 is often referred to as the 'Golden Age' of the country due to the fact that it was at this time that the national epic, The Man in the Panther's Skin was written by Shota Rustaveli and there was a flowering of architecture and painting during this long and prosperous interlude in a region often trampled in the ongoing battles between neighbouring empires.

\section{Peter Brown and the Rise of Late Antique Studies}

This shaping of a national narrative by concentrating on certain events, reigns or individuals who are perceived to have played a pivotal role in the formation of the nation state is, of course, a common phemomenon. However in societies with less of a tradition of advanced studies across the Humanities then the privileging of certain events can cause severe distortion in the historical record. Whilst in Syria we are facing a problem of omission-late antiquity has, until recently, not received as much attention as some other historical epochs, we can compare this lacuna to what has happened to the study of late antiquity elsewhere. The same era was largely overlooked in the west until the work of Peter Brown led the way in a wider revival of interest sparked after the publication of The World of Late Antiquity AD $150-750 .{ }^{18}$ From the 1990 os onwards there has been an explosion in the study of late antiquity as European and American

18 Brown, Peter, The World of Late Antiquity AD150-750, Thames \& Hudson; London, 1989 (First edition 1971). 
scholars have sought to explore a period written off by Gibbon and his followers as a time of terminal decline.

Where this rediscovery of late antiquity has in Syria had the virtue of joining the gaps and providing a linking narrative between the Classical and early Islamic eras, both already the subjects of serious study in the country, in Georgia the study of this period has progressed in a different manner. Lacking a suffciently established archaeological framework for this time, the events of the fourth century CE onwards have largely been viewed through the lens of later medieval texts and the period is almost totally absent from museum displays. So, taking this back to basics and starting at the beginning, what do we know about late antique Kartli in material terms? More specifically, can the information we have tell us anything about how the Georgians of the time were interacting with the rest of the world?

As mentioned above, there has been very little archaeological exploration of this period but there has been some well-documented research into the Classical era occupation of a number of sites in Kartli and, in some cases, these settlements have remained active as late as the third or early fourth centuries CE. In addition there has been continuity of usage in several important burial grounds, which has provided copious evidence of burial traditions over a long period of time. Therefore, although these have not been projects targeting the late antique period, a certain amount of data can be gleaned from work concentrating on the Classical era.

The most famous of these sites are those in the vicinity of Mtskheta, the ancient capital of Kartli, and for our purposes the most significant source of information is the huge burial ground at Samtavro. ${ }^{19}$ This site saw one of its

19 Samtavro cemetary covers almost 20 hectares and was used from the third millennium BCE with peaks in usage in the late Bronze Age and the Iron Age and then again in the late Roman through to late antique period. See p. 1, Sagona, A., Nikolaishvili, V., Sagona, C., Ogleby, C., Pilbrow, V., Briggs, C., Giunashvili, G., Manegaladze, G., 'Excavations at Samtavro, 2008-2009: An Interim Report', Ancient Near Eastern Studies 47 (2010), pp. 1-136. The National Agency for Cultural Heritage Preservation of Georgia puts the chronological span of interrments at the site as dating from the mid third millennium ВСЕ until the tenth century CE at http://www.heritagesites.ge/eng/archeology/archeology/58 (accessed 06.02.2017). Excavation at Samtavro began in the nineteenth century and has continued sporadically ever since. There is currently a project at the Simon Janashia Museum of Georgia to conserve and study the early records of the excavations in order to make the findings of the first expeditions available to contemporary scholars who continue to work on the site, pers. comm. Dr Darejan Kacharava and see Sagona, A., Nikolaishvili, V., Sagona, C., Ogleby, C., Pilbrow, V., Briggs, C., Giunashvili, G., Manegaladze, G., 'Bridging two conti- 
peaks in activity in the fourth and fifth centuries CE - the very time when the process of Christianisation centred on Mtskheta is recorded as occurring in the Georgian historical sources. In actual fact there is a small amount of evidence to suggest that there were some early Christians resident in Mtskheta and its environs as early as the second or third centuries CE with the discovery of two silver rings inset with carnelian intaglios. The two bear almost identical images of two fish flanking a central cross. One intaglio appears to be truncated at the top, which may have led to the two being catalogued as "images of two fish and an anchor"20 One of the rings was discovered in the Samtavro cemetary, but the other is recorded as being found near the national cathedral, Svetiskhoveli, in central Mtskheta and both provide possible evidence of Christians or possibly Judaeo-Christians in Mtskheta up to a century before the official evangelisation of the country.

This evidence of earlier Christian, Jewish or Judaeo-Christian presence is echoed in the town of Urbnisi, which is also mentioned in the Georgian evangelisation narrative and which has been published along with material from Mtskheta by Mgaloblishvili and Gagoshidze. ${ }^{21}$ Naturally the picture of religious practices at this period suggests a certain plurality of practices with Christianity and Judaism co-existing to all appearences peacefully alongside the existing pagan beliefs of the region. This varied picture is represented in the Samtavro funerary evidence where the long bones in early Christian burials appear to have been rearranged in line with pagan practices, ${ }^{22}$ although it is difficult to assign a purely religious motive for the change from tile-lined tombs to the use

nents: Renewed investigations at Samtavro, Georgia', Journal of Archaeology of the Turkish Academy of Sciences/Türkiye Bilimler Akademisi Arkeoloji Dergisi 13 (2010), pp. 313-338.

20 In early 2017 both of these objects were on show in a temporary exhibition at the entrance to the Archaeological Treasury of the Simon Janashia Museum of Georgia. They were displayed with the treasury of the Archaeological Museum of Mtskheta whilst that institution was being renovated. The ring with the truncated cross was catalogued as "Ring with images of two fish and anchor intaglio, Silver, Cornelian, Samtavro Burial 71 2nd to 3rd century AD." The ring with a complete cross was described as "Intaglio with the images of two fish and an anchor, Cornelian, Silver, Svetiskhoveli, Burial 17, 3rd century AD." The intaglios are published in Surguladze, T., Bibiluri, T. \& Dzneladze, M., 'Adreuli kristianobis simbolo mtskhetidan', Bulletin of the Academy of Sciences of the Georgian SSR 101:3 (1981), pp. 741-744.

21 Mgaloblishvili, Tamila \& Gagoshidze, Iulon, 'The Jewish Diaspora and Early Christianity in Georgia', in Mgaloblishvili, Tamila (ed.), Ancient Christianity in the Caucasus, Curzon; Richmond, 1998, pp. 39-58.

22 p. 323, Sagona, A., et al, 'Bridging two continents.' 
of stone cists between the fourth and fifth centuries $\mathrm{CE} .{ }^{23}$ Naturally processes of religious conversion are gradual and a certain degree of syncretism is to be expected in the archaeological record, but the evidence of Mtskheta and Urbnisi does accord with the main points of the vita of St. Nino in suggesting that there was a pre-fourth century Jewish presence in both Urbnisi and Mtskheta and it demonstrates that Christianity was indeed already present in both towns by the fourth century.

\section{The Fourth Century Expansion of Christianity}

This brings us on to our next point. We know that there were many Christians in Syria in the fourth century from the evidence of the abundant extant ecclesiastical architecture alone, without the need to explore the texts or archaeological small finds for the region. Nevertheless it is self-evident that the evidence for early Christian Syria is plentiful in all areas. With Georgia the fact that early references to the fourth century evangelisation of Georgia by a woman were circulating outside the country shortly after the period of conversion, ${ }^{24}$ taken in tandem with the archaeological evidence cited above, strongly supports the view that Kartli was evangelised in the earlier part of the fourth century. In fact some of the archaeological data points to a Christian presence even earlier than this, which would perhaps suggest that the fourth century push for conversion was helped by the existence of some pre-existing Christian communities already established in the territory of Kartli.

Therefore it is mysterious that we do not encounter early church buildings of the same date to complete the picture as we do in Syria, especially in a context where there was already a long-established tradition of building in stone. The insistence of Chubinashvili that small churches dominated early ecclesiastical architecture was tied up with his beliefs that early Georgian churches were influenced by the design of traditional Georgian dwellings known as darbazi houses. These hall-houses had distinctive pyramidal roofs created by overlapping layers of wooden beams and have been posited as the direct inspiration for the centrally-planned churches common throughout the southern Caucasus. ${ }^{25}$ It is this predominance of the (larger) centrally planned type of church

23 ibid.

24 See chapter 1.

25 See for example Chubinashvili, Giorgi N. in an essay translated into English, 'On the initial forms of Christian Churches' in Mgaloblishvili, Tamila (ed.), Ancient Christianity in the Caucasus, Curzon; Richmond, 1998, pp. 185-195. 
building that has added to the belief that church architecture only took off in the fifth or sixth century drawing its inspiration from earlier Georgian domestic architecture. In this reading the basilica form has been perceived as a 'foreign' influence and Georgian scholars have used the floorplans of Butler and Lassus to link the origins of the basilica form and the influences of other cultures to Georgian ecclesiastical architecture. This argument is encountered for example in a consideration of the origins of Georgian martyria:

As is well known, the native Aiadana type building of the classical period of Achaemenid Iran spread across the world in three directions: West, to Syria and Palestine where it played a role in certain so-called SyrianNabatean temples and later in square planned Christian basilicas; North to Iberia and Albania; to Iran itself and, later, in the Islamic world. ${ }^{26}$

These assumptions are often based on outdated arguments that have since been superseded recent research. For example in the argument above, a 1923 article by Butler is cited ${ }^{27}$ and elsewhere Silagadze refers to an article published by Monneret de Villard in $1936 .{ }^{28}$ Even though, as discussed previously, there has been more survey than excavation carried out thus far on late antique Syrian sites, it is still undeniable there has been a great deal of work completed since the interwar period and it is somewhat anachronistic to base arguments purely on the likes of Butler and company in the twenty-first century.

Another limitation encountered with this approach is the fact that many of these comparisons are made solely on the basis of comparing floorplans. This has long been a conventional mode of art historical practice, notably employed in such reference works as Krautheimer's Early Christian and Byzantine Architecture $^{29}$ but as the world shrinks and, with the notable exception of the world's war zones, more and more sites become easily accessible, then questions are

26 Translation by the author, pp. 136-137 Silagadze, Nino, 'Kartuli "saplavs zeda" eklesiebi da mati paralelebi aklo aghmosavletshi', Khelovnebatmtsodneoba 5 (2003), pp. 135-142.

27 Butler, Howard Crosby, 'Nabataean Temple Plans and the Plans of Syrian Churches' in Glück, H. (ed.), Studien zur Kunst des Ostens, Avalun Verlag; Wien \& Hellerau, 1923, pp. 916.

28 p. 136 footnote 4 of Silagadze, Nino, 'Kartuli "saplavs zeda” eklesiebi' mentions Resafa using a reference to Monneret de Villard, H., 'The Fire Temples', Bulletin of the American Institute of Persian Art and Archaeology, 4 (1936), New York, pp. 176-184.

29 Krautheimer, Richard, Early Christian and Byzantine Architecture, Yale University Press; New Haven \& London, 1965, 4th Edition revised by Krautheimer, Richard \& Ćurčić, Slobodan, 1986. 
raised as to the accuracy of this methodology. A superficial similarity at the level of a two dimensional floorplan may be misleading when a variety of other factors are taken into consideration. As Maranci recently commented with regard to seventh century Armenian architecture:

Whilst it seems indisputable that the designers of Zuart'noc' were acquainted with the aisled tetraconch form, one must ask whether it appeared to them as originally built or in a state of renovation, partial collapse, or ruin. ${ }^{30}$

She returns to this point with particular emphasis on the relation of this issue to the Syrian material:

Yet the clear visual similarity of plans veils a much more complex set of problems, requiring close individual consideration of each monument and its potential as a source. Whilst the Syrian and Mesopotamian churches are routinely discussed in connection with the origins of Zuart'noc', few scholars discuss their structural histories or state of preservation at the time of the latter's construction. ${ }^{31}$

In short what may appear to be cut-and-dried cases of similar typology may in fact prove more difficult to substantiate when the respective dates of the monuments in question are closely compared and later innovations or complicated chronological developments are stripped away. If these arguments bear some weight when we discuss a seventh century monument, as Maranci is doing, then we can argue that the search for similarities and archetypes is even more fraught with difficulty when we try to look for relationships between fourth century monuments.

Back in the 1950s Georges Tchalenko had already identified that there was more than one source of inspiration for fourth century Syrian basilicas. Whereas the link between these new ritual spaces and the Roman civic basilica was clear, they could also draw upon more humble domestic spaces for influence. ${ }^{32}$ Tchalenko identified one of the earliest churches on the Syrian limestone massif as being adapted from the plan for neighbouring provincial villas and this

30 p. 116, Maranci, Christina, Vigilant Powers: Three Churches of Early Medieval Armenia, Brepols; Turnhout, 2015 .

31 p. 127, ibid.

32 p. 151, Tchalenko, Georges, Églises syriennes à bêma. Bibliothèque archéologique et historique 105, Paul Geuthner; Paris, 1990. 
case once again highlights the problems of relying solely on Butler's interpretation of church evolution. Taking issue with Butler's assertion that the church and the neighbouring villa in the hamlet of Qirq Bizeh were contemporary with each other, and that one villa had later been altered to function as an early church, Tchalenko instead sought to demonstrate that the church was built several decades later than the neighbouring house and was designed specifically for use as a chapel. ${ }^{33} \mathrm{He}$ posited that this was the first building on the limestone massif that was built specifically for use as a church, which would have made it the next logical step onwards from the use of modified domestic spaces evidenced at Dura Europos in the preceding century. His reasoning was that the earlier part of the fourth century was still an experimental period for Christian architecture and, out in the rural hinterland of Antioch, it was more logical for the patrons of country estates to adapt familiar forms of domestic architecture than to emulate the urban civic basilica; the familiarity of the rural villa would have been relatively simple for a local workforce to alter to meet ritual needs and for these reasons Tchalenko argued that Qirq Bizeh offered a variant strain feeding into the origins of the simple hall church. ${ }^{34}$

This argument offers an alternative to the view that single-naved hall churches evolved almost completely from the same root as the early basilica form, which derived from Roman civic basilicas ${ }^{35}$ and it can also offer a possible explanation as to why a significant proportion of the churches of the limestone massif terminate in a flat east end rather than a semi-circular apse. The author has, in the past, ${ }^{36}$ like many others viewed this phenomenon as linked to interactions with Mesopotamia where there was a tradition of flat walled cellae $e^{37}$ in local temples, but Tchalenko's suggestion of a variant strand of domestic influence offers a more local, vernacular reading to explain the occurrence of small churches terminating in flat east walls in northwest Syria. The suggestion that in the fourth century the emergence of church architecture was formed

33 p. 151, ibid.

34 p. 151, ibid.

35 pp. 202-203, Krautheimer, Richard, Early Christian and Byzantine Architecture, Yale University Press; New Haven \& London, 1965, 4th Edition revised by Krautheimer, Richard \& Ćurčić, Slobodan, 1986.

36 p. 18, Loosley, Emma, The Architecture and Liturgy of the Bema in Fourth to Sixth-Century Syrian Churches, USEK, Patrimoine Syriaque vol. 2; Kaslik, Lebanon, 2003 (re-issued in a second edition by Brill, 2012).

37 For a discussion of this issue see Loosley, Emma, 'Syria' in Caraher, William, Davis, Thomas and Pettegrew, David K. (eds.), The Oxford Handbook of Early Christian Archaeology, Oxford University Press; New York \& Oxford, forthcoming. 
as much by vernacular influences as it was by larger pan-imperial architectural developments could offer the key to the interpretation of the earliest Christian ritual spaces in a variety of more remote and/or rural locations that were situated a significant distance from the major cities and their more cosmopolitan cultures.

\section{A Kakhetian Case Study: Nekresi Monastery and Its Environs}

Recently archaeological evidence has come to light in Kakheti in eastern Georgia that intriguingly mirrors the fourth-century evidence in Syria. Excavations undertaken by the Simon Janashia State Museum of Georgia at Chabukauri and Dolochopi, both in the territory of Nekresi, seem likely to rewrite our understanding of the earliest Christian architecture in Georgia. ${ }^{38}$ Ironically Nekresi monastery was put forward by Chubinashvili as the earliest extant example of Georgian ecclesiastical architecture with the ungainly structure that he dubbed a 'basilica' described as being a fourth century proto-basilica (Fig. 1). ${ }^{39}$ This interpretation has now been disproved with archaeological excavation at the site of the monastery finding no evidence of any occupation at the site earlier than the sixth century ${ }^{40}$ and the 'fourth century basilica' is now definitively

38 The discussion that follows is possible thanks to the collegiality and generosity of Professor Nodar Bakhtadze of the Simon Janashia State Museum of Georgia and Ilia State University. Professor Bakhtadze was kind enough to host the author at the 2016 and 2017 excavations at Dolochopi basilica and to offer access to his research, both published and unpublished, for the author to study in addition to accompanying her on site visits to Nekresi and arranging for her to visit Chabukauri. For further information on the excavations please consult Baktadze, Nodar, 'Dolochopis bazilikaze 2012 tsels chatarebuli arkeologiuri kvlevis angarishi', Kadmosi 4 (2012), pp. 273-303, Baktadze, Nodar, Mamiashvili, Vazha \& Gabekhadze, Bachana, 'Dolochopis bazilikis arkeologiuri kvleva nakalakar Nekresshi', Onlain arkeologia 8, pp. 110-133 (downloaded from https://www .heritagesites.ge/ka/files/98 17.08.2016), Baktadze, Nodar, 'Qvarelis durujispirira bazilikis arkeologiuri kvlevis shedegebi', Sakartvelos erovnuli muzeumis moambe: Sazogadoebriv metsnierebata seria 4 (49B) (2013), pp. 175-198 and Baktadze, Nodar, 'Archeological Research upon One of the Earliest Georgian Christian Basilica', Temporis Signa: Archeologia della tarda antichità e del medioevo IX (2014), pp. 65-73. For Nekresi monastery see Baktadze, Nodar, Tevdorashvili, Natela \& Bagrationi, Giorgi, Nekresi. Tsnobarimomlotsvelta da mogzaurtatvis, Nekresi, 2010.

39 Bakthtadze, Nodar, 'The Oldest Basilicas Revealed in Nekresi Former City and Hypotheses on the Architectural Design of the First Georgian Christian Churches', Jena, 2017 (forthcoming).

Nodar Bakhtadze, pers. comm. 


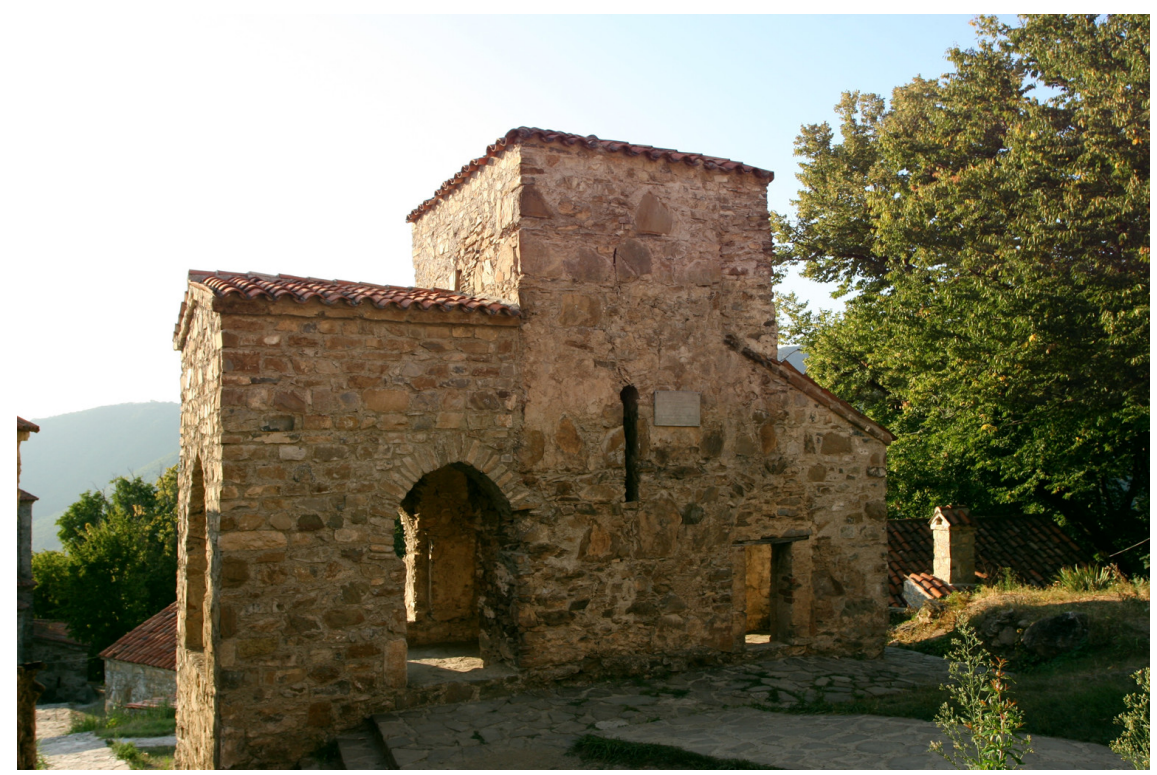

FIGURE $1 \quad$ Nekresi 'basilica' looking west

identified as a sixth century mortuary chapel that bears extensive evidence of pilgrims collecting eulogiae at the site in the form of oil that had passed over the bones of the saints. These early holy men were presumably monks at the monastery who were interred in the crypt beneath the main floor of the small structure that is atypically open to the elements on all four sides and therefore bears no relation at all to a conventional basilica.

This concentration on the site of the monastery itself has, in the past, overlooked the fact that the territories around Nekresi were densely populated in earlier periods. A series of archaeological excavations to the west, south and east of the monastic site have produced a picture of a vibrant and cosmopolitan society that flourished until a series of natural disasters and the depredations of the Arabs led to a terminal decline for the region in the second half of the first millennium CE. ${ }^{41}$ The rise and fall of religions is also a factor in this process as the location of Nekresi in the far east of Georgia meant that it was always firmly under Persian hegemony. Until the excavations on the monastery site it had long been assumed that Nekresi was founded on the place of a Zoroastrian fire temple. This assumption was logical in that the monastery is linked with the

41 To the north the monastery abuts the foothills of the High Caucasus range meaning that the territory is too mountainous to be suitable for large settlements. 
personage of St. Abibos Nekreseli, one of the Thirteen (As)Syrian Fathers who was martyred by the Persians for pouring water on one of their holy fires in his attempt to prove the falsity of the Zoroastrian faith. ${ }^{42} \mathrm{~A}$ belief that Nekresi was built on the place where Abibos quenched the fire seemed natural given that many fire temples are deliberately sited in high places. However this belief was anachronistic when taken in conjunction with the accepted interpretation that the monastery buildings dated from the fourth century, when according to the tradition of the (As)Syrian Fathers, Abibos is believed to have been martyred in the sixth century.

Once again, archaeological excavation appears to have offered at least a partial solution in explaining the relationship of Christianity with the earlier faiths practised in the region. At the end of the twentieth century a large complex dated to the second- to third-century CE was excavated in arable fields to the south of the hill on which Nekresi monastery stands. This has been identified as a Zoroastrian fire temple and solves part of the puzzle for us-early Christian monuments are often sited deliberately on top of earlier cult complexes, but it is not unknown for them to alternatively be placed in a manner that sets them in deliberate opposition with an earlier faith. One example from Syria would be the fact that Symeon Stylites the Elder deliberately set up his pillar on a hill to the north of the pagan holy place on the top of Jebel Sheikh Barakat (the Mountain of the Old Man of Blessings). In this way he was spared the possible 'contagion' of standing on soil perceived to be tainted by paganism, but his presence signalled that there was a new, more powerful, God present in the valley. On this occasion it is not unreasonable to argue that the building of a monastery on the peak overlooking the former Zoroastrian temple was intended as a strong visual statement of the supremacy of the Christian faith.

In 2004 a further season established that the temple was aligned with the summer and winter solstices suggesting that it possibly incorporated some element of solar worship into the rituals carried out at the site. ${ }^{43}$ The late twentieth century excavation had yielded ceramics of the second, third and fourth centuries and charcoal from a threshold gave a radiocarbon date in the fifth century suggesting that the complex was destroyed at that time. ${ }^{44}$ Naturally the interpretation of this event was that some form of religious persecution

\footnotetext{
42 pp. 218-225, vol. 4 (1968), Abuladze, Ilia, Dzveli kartuli agiograpiuli literaturis dzeglebi, 6 vols., Gamomtsemloba 'Metsniereba'; Tbilisi, 1963-1989.

43 Simonia, Irakli, Ruggles, Clive \& Bakhtadze, Nodar, 'An Astronomical Investigation of the Seventeen Hundred Year Old Nekresi Fire Temple in the Eastern Part of Georgia', Journal of Astronomical History and Heritage 12:3 (2009), pp. 235-239. 
occurred, possibly caused by the increasing confidence of the Christians, which ended in the destruction of the temple. An alternate reading is offered by Kipiani who argues that the spatial organisation of the complex is not compatible with that of a fire temple and, taking into account the astrological elements of the temple planning noted by the 2004 excavation team, he posits the theory that this complex was in actual fact a Manichaean monastic complex. ${ }^{45}$ His arguments are echoed by those of Mgaloblishvili and Rapp who have also discussed the evidence for the presence of Manichaeans in eastern Georgia, suggesting that the faith may have persisted in certain regions until the sixth century. ${ }^{46}$ Intriguingly Kipiani also argues that this 'Manichaean' architecture could have provided the inspiration for the phenomenon of the Georgian 'triple church basilica' a unique form of ecclesiastical architecture that we will discuss at length later in this work. ${ }^{47}$

Leaving aside for the moment the issues raised by the possibility that Nekresi was a bastion of Manichaeism rather than Zoroastrianism in late antiquity, the evidence from the temple shows clearly that by the fifth century the earlier faith was viewed as obsolete and a new religion, Christianity, had become dominant in the territory of Nekresi. However if the temple was destroyed in the fifth century and the monastery was not constructed until the sixth century, where did the faithful worship in the intervening century? In addition Nekresi is a monastic complex and would not have met the daily needs of the local laity. Where were they worshipping?

\section{Nekresi Continued: The Lost Cities of Chabukauri and Dolochopi}

The answers to these questions are slowly being answered by excavations at sites to the east and west of Nekresi and the temple. Just over one kilometre to the northwest of the temple complex a substantial basilica was uncovered at the end of the twentieth century (Fig. 2). Far from being a small church designed to hold only a handful or worshippers as conventional Georgian interpretations of ecclesiastical architecture had argued, this basilica on the 'socalled Chabukauri plot' 48 measured over 33 metres along the longitudinal axis

\footnotetext{
45 Kipiani, Guram, 'Nekresis “didi kvadrati”, Kadmosi 1 (2009), pp. 214-251.

46 Mgaloblishvili, Tamila \& Rapp Jr., Stephen H., 'Manichaeism in Late Antique Georgia?', in Van den Berg, Jacob Albert (ed.), In Search of Truth: Manichaica, Augustiniana and Varia Gnostica, Brill; Leiden and Boston, 2011, pp. 263-29o.

47 See chapter 5 .

48 p. 65, Baktadze, Nodar, 'Archeological Research upon One of the Earliest Georgian Chris-
} 


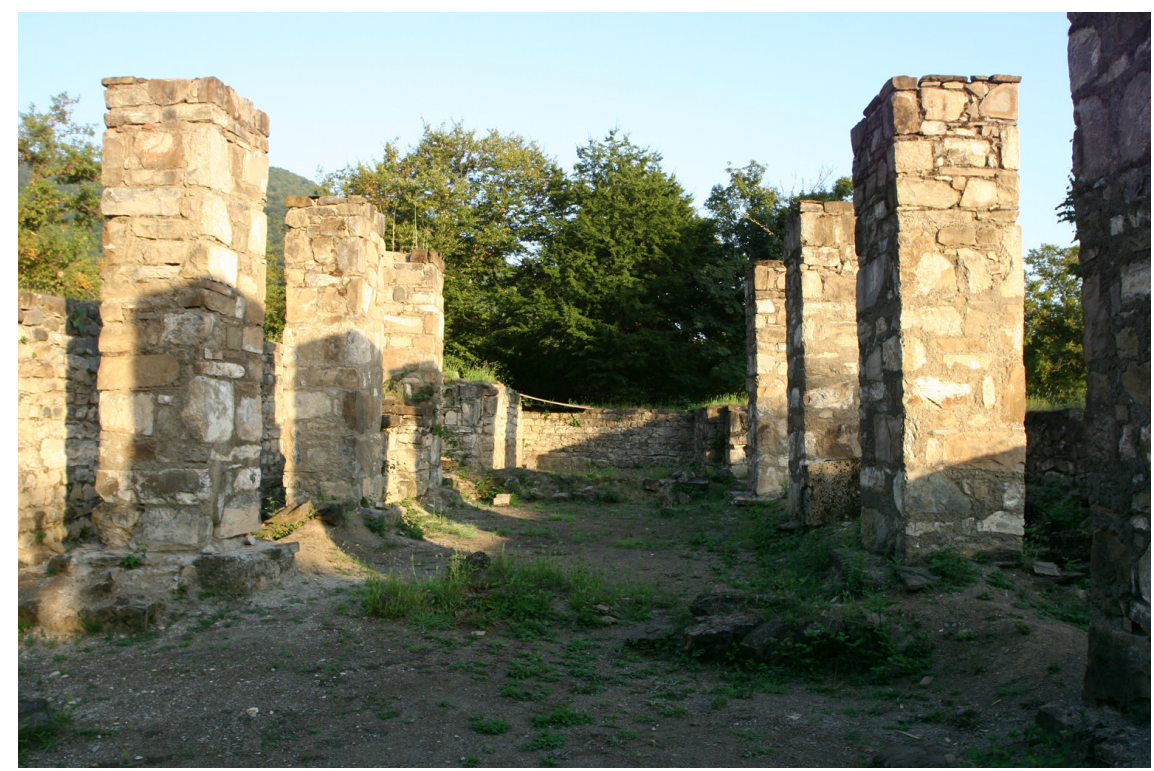

FIGURE 2 View looking east in the main nave of Chabukauri basilica

and was 15 metres wide making it an exceptionally large early basilica. This size would have been deemed impressive in Syria or Asia Minor at this time, given that the small finds from the site pointed to a fourth century date for this church. Interestingly, shortly after its construction the stucture appeared to have been fatally compromised - with the destruction believed to have been caused by an earthquake - and a smaller basilica was built utilising part of the northern aisle of the original structure as the south wall of this new church. ${ }^{49}$ Evidence from the later building put its period of usage as being the fifth and sixth centuries and the timing of this complex, along with its close proximity to the former temple across the rolling arable land at the foot of the Caucasus, suggested that at last the question of how and where people worshiped after the destruction of the temple was answered. More interestingly perhaps, the dates suggested a period of overlap where substantial places of Christian worship were built before the local temple was destroyed. This seems a much more logical chronology as it presents us with a view of a Zoroastrian (or Manichaean)

tian Basilica', Temporis Signa: Archeologia della tarda antichità e del medioevo IX (2014), pp. $65^{-73}$.

49 Interestingly this second church has a synthronon. Only two basilicas in Kartli, one at Chabukauri and the other at nearby Dolochopi, are known to possess this liturgical feature. See chapter 6 for a discussion of the liturgy and liturgical furniture. 


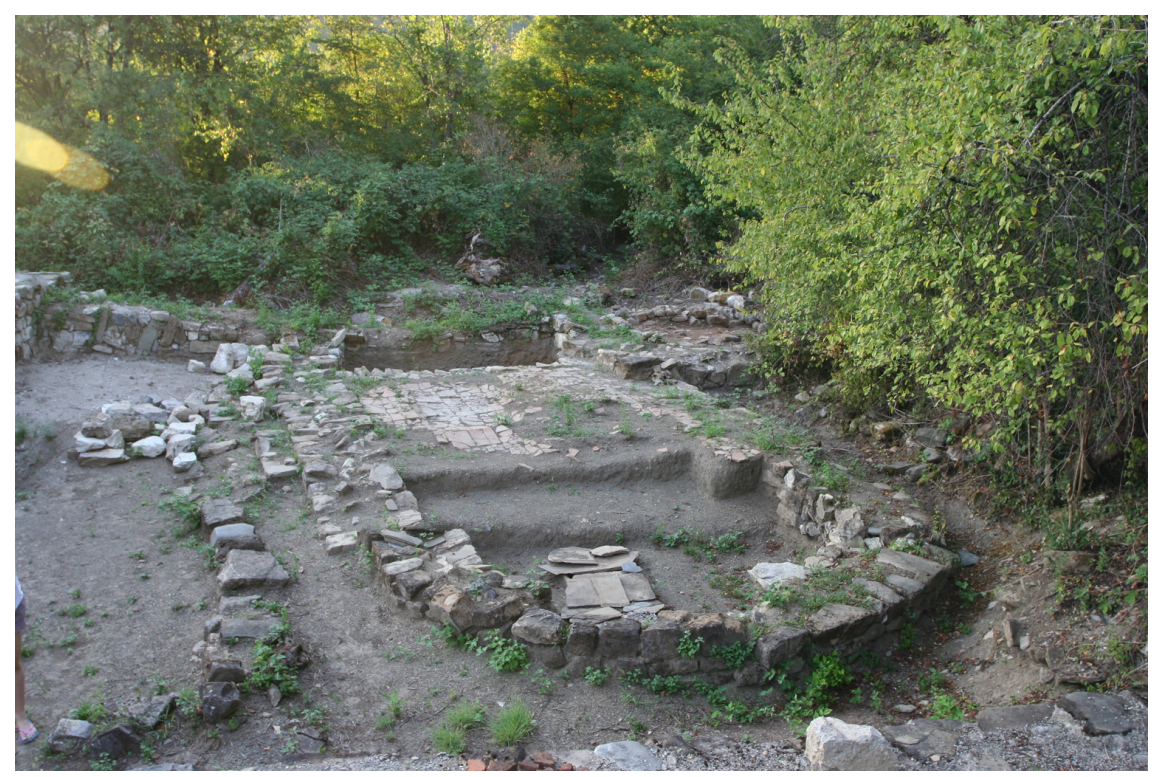

FIGURE 3 Apsed structure of unknown function north of Chabukauri basilica

temple slowly declining over the course of a century as more and more locals chose to adopt the new (Christian) faith, until eventually it became redundant and was burned and looted of its valuable stone for new building projects.

But this discovery of a presumed fourth-century basilica marked only the beginning of the exploratory process and, in a number of ways, raised far more questions than it answered. For example an earlier apsed structure was uncovered to the northwest of the basilica and the beautifully fired terracotta tiles used to pave this structure provide an indication of the importance of this building, even if its function currently remains unknown (Fig. 3). The excavation of this terracotta-paved apse also highlighted the fact that, due to the dense scrubby undergrowth surrounding the basilica, it was very difficult to place this impressive discovery within a wider context. At the time of writing, basic questions such as how far the boundaries of this late antique/early medieval settlement reached at its furthest extent or whether there were any other churches within the town still remain. Nor have there been any answers to questions relating to just when this settlement was founded or even when it was finally abandoned, allowing the scrubby foliage at the furthest foothills of the Caucasus to envelop it once more.

The situation then became even more complex in 2012 when an excavation began to the east of Nekresi. The new excavation was just over four kilometres east of the temple complex as the crow flies, but the route is more circuitous in 


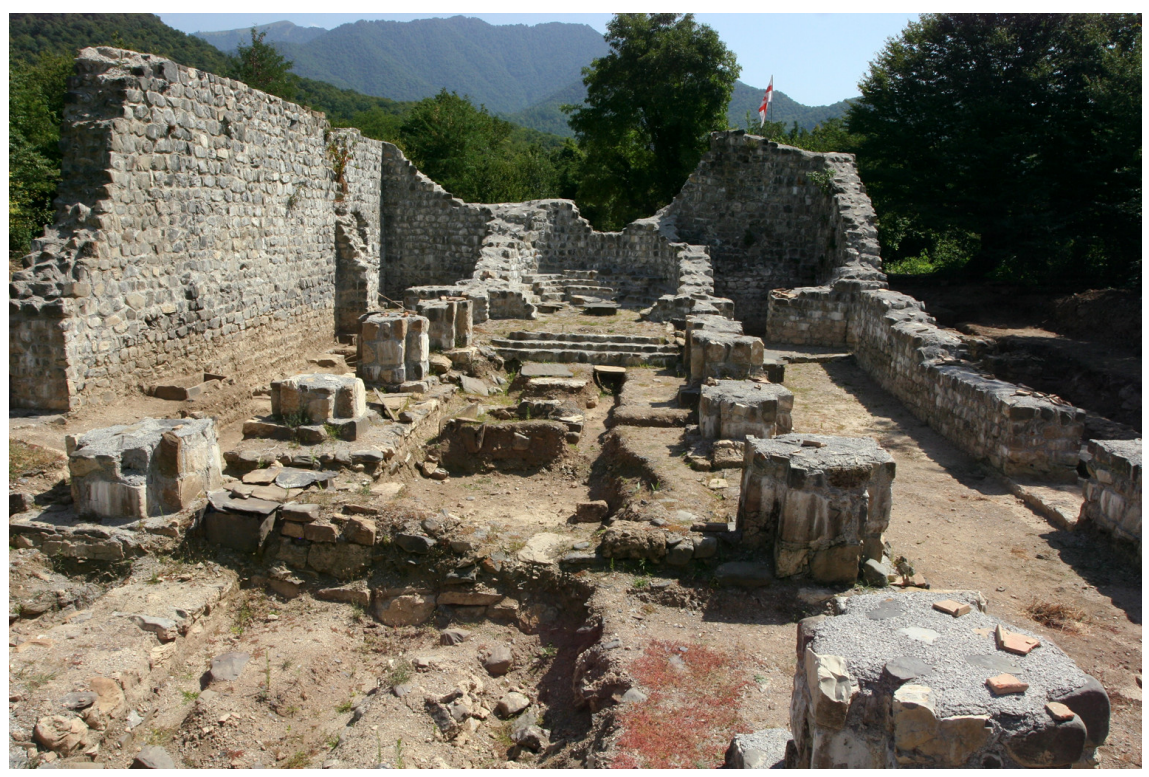

FIGURE 4 Dolochopi basilica looking east

reality as a high, densely forested hill stands between the two sites. This place was called Dolochopi after a long abandoned village in that area and was hidden in the forest on the west bank of the Duruji River. ${ }^{50}$ Once again a huge basilica was uncovered-in this case it was 36 metres by 18.5 metres in its central three naved section, but had further aisles added to both north and south in the style of the typical "three church basilica" that will be discussed later in this volume. This substantial building seemed to date to the fifth century and further excavation revealed that it was the second basilica on the site (Fig. 4). In this case radiocarbon dating has confirmed that the earlier church was a fourth century structure that appears to have burned down and been replaced in the early fifth century by the impressive basilica, that then appears to have suffered possible earthquake damage at the same time as the first church at Chabukauri. ${ }^{51}$

Once again the excavators were faced with a substantial basilica almost in a vacuum. The evidence pointed to a wealthy and thriving Christian community in Dolochopi by the fourth century and, based on data from the basilica, earth-

$5^{\circ} \quad$ See note 38 above for more information on these excavations.

$5^{1} \quad$ Results of samples submitting for tested have yielded dates of $387 \mathrm{CE}$ ( $93.2 \%$ probability), SUERC-70629 and between $388 \mathrm{CE}(68.2 \%)$ and $401 \mathrm{CE}$ (95.4\%), SUERC-76888. 
quake damage and a destruction event suggested that although the complex was active for several centuries, it then declined although local people continued to use the east end of the northernmost aisle as a mortuary chapel until the twelfth or thirteenth centuries. ${ }^{52}$ This paints a clear picture of a settlement that was expanding until natural factors such as earthquakes and the fact that the region was plundered by both the Persians and the Arabs in the first millennium CE all contributed to a terminal decline. The mortuary evidence proves that people were living in a village in the region until the peak of the Middle Ages, but then it seems that the settlement died out completely. However, once again, dense foliage-in this case not low-lying shrubs but established deciduous forest-has envelopped the site and therefore there is currently no way of establishing the parameters of the town on this site and answering such simple questions as to whether this was the only church in Dolochopi or whether there were other civic or cult buildings present in late antiquity at this place.

\section{Archaeological Excavation versus Survey Evidence}

We will be returning to the evidence from the churches in Nekresi territory later in this book, but this brief introduction to these sites has been to highlight the fact that, as in Syria and the re-evaluation of the late antique landscape carried out in the late twentieth and early twenty-first centuries, evidence gained from archaeological excavation has so far proved that the situation appears to have been very different from the interpretation advanced by Chubinashvili and his followers. Whilst early Christian archaeology remains in its infancy in Georgia as a distinct sub-field of archaeology we must note that initial conclusions must be viewed as provisional. On the other hand, thus far they suggest that it is time for us to completely re-think our interpretations of early Christian society in Georgia.

These findings fit with our experience of Syria where the move from survey alone, towards a methodology that employs survey and excavation data in tandem, have proved that the best results are achieved by combining a variety of research methods to fully explore a problem. With this in mind we shall now turn to the 'small finds,' the portable objects discovered in excavations or kept for generations in church treasuries, in order to see if they offer any suggestion of a Syrian-Georgian relationship in late antiquity.

52 Pers. comm. from time spent at the 2016 season of excavations at Dolochopi. 